\title{
Minimal Hepatic Encephalopathy: The Reality Beyond Our Eyes
}

\author{
Encefalopatia Hepática Mínima: Uma Realidade Escondida
}

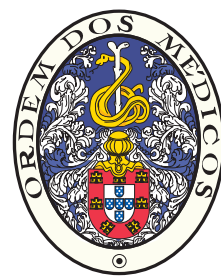

\author{
Mara BARBOSA ${ }^{1}$, Carla MARINHO ${ }^{1}$, Paula MOTA², José COTTER ${ }^{1}$ \\ Acta Med Port 2015 Jul-Aug;28(4):480-485
}

ABSTRACT

Introduction: Minimal hepatic encephalopathy refers to a mild neurocognitive impairment not detectable by clinical examination that can be present in cirrhotic patients.

Aim: To determine the prevalence of minimal hepatic encephalopathy in a secondary healthcare center in Northern Portugal.

Material and Methods: A cross-sectional study was conducted. Cirrhotic outpatients were included. Exclusion criteria: overt hepatic encephalopathy, illiteracy, active alcohol consumption, psychotropic drug use and therapy with lactulose. The presence of minimal hepatic encephalopathy was defined as a value $\leq-4$ on the Psychometric Hepatic Encephalopathy Score, calculated according to the Portuguese norms. Variables analyzed: etiology and severity of liver disease and venous blood ammonia concentration. $p$ values < 0.05 were considered significant.

Results: From the 102 patients who were evaluated, 41 were included: 31 males, mean age $57 \pm 10$ years, mean education $5 \pm 2$ years, 31 in Child-Pugh class A, mean MELD score $6 \pm 3$. Minimal hepatic encephalopathy was diagnosed in $14(34 \%)$ patients. The presence of minimal hepatic encephalopathy was unrelated to severity of liver disease. Despite being more elevated, the mean venous ammonia concentration in minimal hepatic encephalopathy patients was not statistically different from the mean venous ammonia concentration in non-minimal hepatic encephalopathy patients ( $48.5 \pm 13.3$ vs. $45.6 \pm 15.6 \mu \mathrm{mol} / \mathrm{L}, p=0.555)$.

Discussion: The prevalence of minimal hepatic encephalopathy reported is in accordance with the international published data.

Conclusion: Minimal hepatic encephalopathy is a frequent condition that is present early in the course of cirrhosis, even in compensated cirrhotic patients. Therefore, this hidden entity should be actively pursued and managed properly.

Keywords: Hepatic Encephalopathy; Liver Cirrhosis; Neuropsychological Tests; Psychometrics.

\section{RESUMO}

Introdução: A encefalopatia hepática mínima define-se como um défice neurocognitivo ligeiro, não detectável ao exame clínico, que pode estar presente nos doentes cirróticos.

Objectivo: Determinar a prevalência da encefalopatia hepática mínima num hospital prestador de cuidados de saúde secundários no Norte de Portugal.

Material e Métodos: Realizou-se um estudo transversal em que foram incluídos os doentes cirróticos seguidos na consulta externa. Critérios de exclusão: encefalopatia hepática clínica, iliteracia, consumo activo de álcool e terapêutica com fármacos psicotrópicos ou lactulose. A presença de encefalopatia hepática mínima foi definida como um valor $\leq-4$ na Pontuação Psicométrica da Encefalopatia Hepática, calculado de acordo com as normas portuguesas. Analisaram-se as variáveis: etiologia e gravidade da doença hepática e concentração da amónia sanguínea venosa. Considerou-se o valor de $p<0,05$ como significativo.

Resultados: Dos 102 doentes avaliados, 41 foram incluídos: 31 homens, idade média de $57 \pm 10$ anos, escolaridade média de $5 \pm 2$ anos, 31 Child-Pugh classe A, score MELD médio de $6 \pm 3$. Foi diagnosticada encefalopatia hepática mínima em 14 ( $34 \%$ ) doentes. A presença de encefalopatia hepática mínima não se relacionou com a gravidade da doença hepática. Apesar de mais elevado, o valor médio da concentração da amónia venosa nos doentes com encefalopatia hepática mínima não foi significativamente diferente do valor médio da concentração da amónia venosa nos doentes sem encefalopatia hepática mínima (48,5 $\pm 13,3 \mathrm{vs}$. 45,6 \pm 15,6 $\mu \mathrm{mol} / \mathrm{L}$, $p=0,555)$.

Discussão: A prevalência da encefalopatia hepática mínima descrita está de acordo com os dados internacionais.

Conclusão: A encefalopatia hepática mínima é uma entidade frequente que está presente precocemente na história natural da cirrose, mesmo em doentes compensados. Consequentemente, esta condição escondida deve ser activamente procurada e os doentes devidamente orientados após o diagnóstico.

Palavras-chave: Cirrose Hepática; Encefalopatia Hepática; Psicometria; Testes Neuropsicológicos.

\section{INTRODUCTION}

Minimal hepatic encephalopathy (MHE) is characterized by a mild neurocognitive impairment encompassing neuropsychological and neurophysiological alterations not detectable by clinical examination. ${ }^{1,2}$ MHE is considered the initial phase of the spectrum of hepatic encephalopathy $(\mathrm{HE})^{3}$ in patients with cirrhosis and in non-cirrhotic patients with porto-systemic shunting. ${ }^{4}$ The neurocognitive domains more commonly affected in MHE are the attention, the visuospatial abilities and the fine motor skills. ${ }^{1,5,6}$ Also, diminuished memory performance has been described, not due to primary disturbances, ${ }^{7,8}$ but mainly as a consequence of the impaired cognitive process (attention and visual perception deficits). ${ }^{8,9}$

MHE has a negative impact on daily life activities and

1. Serviço de Gastrenterologia. Centro Hospitalar do Alto Ave. Guimarães. Portugal.

2. Serviço de Patologia Clínica. Centro Hospitalar do Alto Ave. Guimarães. Portugal.

$\bowtie$ Autor correspondente: Mara Barbosa. maraisabelbarbosa@net.sapo.pt

Recebido: 26 de Novembro de 2014 - Aceite: 26 de Abril de 2015 | Copyright @ Ordem dos Médicos 2015 
working capacity, ${ }^{10}$ affects health-related quality of life (HRQoL), ${ }^{11-15}$ impairs fitness to drive, ${ }^{16-18}$ is associated with motor vehicle crashes $^{19,20}$ and predisposes the patient to falls. ${ }^{20,21}$ Furthermore, MHE is of prognostic significance as it is a risk factor for the development of overt $\mathrm{HE}^{20,22-25}$ and death. ${ }^{20,26}$

Recognizing MHE is important because its treatment can improve cognitive functions ${ }^{27-31}$ and quality of life, ${ }^{27-29,31,32}$ and avert progression to overt HE. ${ }^{28,30}$ However, there is no consensus regarding the most adequate screening test. ${ }^{33,34}$ Several tools to detect MHE have been proposed, including neuropsychological testing (such as Psychometric Hepatic Encephalopathy Score (PHES), ${ }^{33}$ Repeatable Battery for Assessment of Neuropsychological Status (RBANS), ${ }^{33}$ Inhibitory Control Test, ${ }^{35}$ Continuous Reaction Time Test $^{34,36}$ ), electroencephalogram spectral analysis/evoked potentials $^{33,37-40}$ and critical flicker frequency. ${ }^{33,34,36,41,42}$ Comparing with the other approaches, the psychometric testing is the most robust diagnostic method because it directly assesses the cognitive functions which are impaired in MHE and is more extensively validated. ${ }^{33,36}$

The PHES has been recently recommended by the International Society on Hepatic Encephalopathy and Nitrogen Metabolism for the neuropsychological assessment of patients with liver disease. ${ }^{33}$ Only this battery has been specifically developed for the diagnosis of MHE. ${ }^{5}$ The PHES combines five easily applicable paper-andpencil psychometric tests: the Number Connection Test-A, the Number Connection Test-B, the Digit Symbol Test, the Serial Dotting Test and the Line Drawing Test. ${ }^{5}$ It has already been normalized for the Portuguese population. ${ }^{43}$

\section{AIM}

Our study aimed at determining the prevalence of MHE in a secondary healthcare center in Northern Portugal, as there is no national data regarding this issue.

\section{MATERIAL AND METHODS \\ Study population}

A cross-sectional study was conducted. Cirrhotic outpatients followed at our department for more than six months were included. The diagnosis of cirrhosis was based on clinical, biochemical, ultrasonographic, endoscopic and, when available, histological criteria. Exclusion criteria were: overt EH, illiteracy, active alcohol consumption (alcohol abstinence was defined as no alcohol drinking for a minimum period of 3 months), psychotropic drug use, therapy with lactulose, severe systemic diseases that could affect the cognitive function (renal, pulmonary, cardiac, psychiatric, neurological, infectious, including HIV, and endocrine diseases) and structural brain changes documented on imagiological studies (computed tomography or magnetic resonance imaging). All participants gave written informed consent.

\section{Clinical and analytical data}

Data regarding gender, age, education years and etiology of liver disease were collected. Severity of liver disease was assessed by Child-Pugh classification and model for end-stage liver disease (MELD). Laboratory parameters (hematological, biochemical and clotting profiles and ammonia concentration) were measured in overnight fasting venous blood samples. Venous ammonia samples were cooled and processed immediately after blood collection.

\section{Neuropsychological assessment}

Patients were considered as not having detectable clinical dysfunction if they were included in stage 0 of West Haven Criteria and if neurological and physical examinations were unremarkable.

A diagnosis of MHE was made when the PHES was $\leq$ -4. The PHES was calculated according to the Portuguese norms (adjusted for age and level of education). ${ }^{43}$ As PHES is already normalized for the Portuguese population a control group is not required. The psychometric battery was administered in a closed, quiet and well-illuminated room. A practice run was administered for all tests. Time interval between venous ammonia samples and neuropsychological evaluation was less than 24 hours.

\section{Statistical analysis}

Table 1 - Baseline characteristics of cirrhotic patients

\begin{tabular}{|c|c|}
\hline & Patients $n=41$ \\
\hline Gender (male) n (\%) & $31(76 \%)$ \\
\hline Age (years) & $57 \pm 10$ \\
\hline Mean education (years) & $5 \pm 2$ \\
\hline \multicolumn{2}{|l|}{ Cirrhosis etiology n (\%) } \\
\hline alcoholic & $33(81 \%)$ \\
\hline viral & $4(10 \%)$ \\
\hline alcoholic + viral & $2(5 \%)$ \\
\hline primary biliary cirrhosis & $1(2 \%)$ \\
\hline hemochromatosis & $1(2 \%)$ \\
\hline Child-Pugh score (units) & $6 \pm 1$ \\
\hline \multicolumn{2}{|l|}{ Child-Pugh class n (\%) } \\
\hline A & $31(76 \%)$ \\
\hline B & $10(24 \%)$ \\
\hline MELD score (units) & $6 \pm 3$ \\
\hline Ascites n (\%) & $4(10 \%)$ \\
\hline Gastroesophageal varices $n(\%)$ & $33(80 \%)$ \\
\hline Hemoglobin (g/dL) & $13.9 \pm 1.6$ \\
\hline Sodium (mEq/L) & $139.3 \pm 3.6$ \\
\hline Creatinine (mg/dL) & $0.8 \pm 0.2$ \\
\hline Albumin (g/dL) & $3.7 \pm 0.5$ \\
\hline INR & $1.2 \pm 0.2$ \\
\hline Ammonia $(\mu \mathrm{mol} / \mathrm{L})$ & $46.6 \pm 14.7$ \\
\hline
\end{tabular}


Statistical analysis was performed using SPSS 16.0 for Windows (SPSS INC. Chicago, IL, USA). Variables with normal distribution were expressed as mean \pm standard deviation (SD) and variables with non-normal distribution as median and range. Student's $t$-test, Fisher's Exact Test and Pearson's correlation were used when appropriated. $p$ values $<0.05$ were considered as significant.

\section{RESULTS}

From the 102 patients who were evaluated (almost all of them had been followed in our department for a period of more than one year), only 41 had eligible criteria: 31 (76\%) males, mean age $57 \pm 10$ years, mean education $5 \pm 2$ years. The etiology of liver disease was predominantly alcoholic $(85 \%)$. Regarding severity of liver disease, the majority of patients $(76 \%)$ were compensated (Child-Pugh class A). Mean MELD score was $6 \pm 3$. Mean ammonia concentration was $46.6 \pm 14.7 \mu \mathrm{mol} / \mathrm{L}$. Baseline characteristics of patients are listed in Table 1.

MHE was diagnosed in $14(34 \%)$ patients. The characteristics of patients with and without MHE are listed in Table 2. The presence of MHE was similar in alcoholic and non-alcoholic patients. Concerning severity of liver disease and $\mathrm{MHE}$, there was not a significant difference between Child-Pugh class A and B patients; however, patients with MHE tended to have higher MELD score. Also, lower hemoglobin values tended to correlate with the presence of MHE. Although more elevated, the mean venous ammonia concentration in MHE patients was not statistically different from the mean venous ammonia concentration in non-MHE patients $(48.5 \pm 13.3$ vs. $45.6 \pm 15.6 \mu \mathrm{mol} / \mathrm{L}, p=0.555)$. Child-Pugh class $B$ patients had significant higher mean venous ammonia concentration values comparing with class A patients $(54.9 \pm 18.7$ vs. $43.9 \pm 12.4 \mu \mathrm{mol} / \mathrm{L}, p=0.038)$. Also, venous ammonia concentration values were positively correlated with MELD score $(\rho=0.401, p=0.009)$.

\section{DISCUSSION}

In our study, $34 \%$ of patients were diagnosed with MHE, which is in accordance with the prevalence reported in different studies, ranging from 20 to $80 \%,{ }^{38}$ depending on the population that has been selected and on the diagnostic test adopted. The neuropsychological tests, such as the PHES that was used in this study, are considered the gold standard to assess MHE. ${ }^{33}$ However, some caution is necessary when using them, as they have some limitations: the learning effect, which is observed when there is necessary to apply it more than once as in follow-up examinations, ${ }^{33}$ and the fact that their results are influenced by variables such as age, education, language, visual impairment, medicaments and alcohol consumption.,33 There are alternate forms of psychometric tests (PHES has 4 parallel versions) ${ }^{5,33}$ so the practice learning effects in repetitive studies can be eliminated. ${ }^{3,5,33}$ Although the results of psychometric tests can be corrected by age and by degree of education, as it was done in our data, the other variables are more difficult to control. In prospective research this is managed by not enrolling these patients, but in daily clinical practice this problem persists. In order to try to overcome all of these limitations, there has been an effort to identify a biological or a psychophysiological marker that could be a surrogate of MHE. However, more validation studies are needed in this field.

In our population, the presence of MHE was unrelated to the severity of liver function evaluated by Child-Pugh classification and MELD score, although there was a statistical tendency to patients with higher MELD scores to present with MHE. Some controversy exists concerning this point, with some studies establishing a definitive relationship between severity of liver function and $\mathrm{MHE}^{20,26,44-}$ ${ }^{47}$ and others not. ${ }^{29,48-50}$ The absence of Child-Pugh class C patients, as all of them (8 out of 102) presented with exclusion criteria (overt EH, psychiatric disease, chronic

Table 2 - The characteristics of patients with and without minimal hepatic encephalopathy

\begin{tabular}{|c|c|c|c|}
\hline & MHE $(n=14)$ & Non-MHE $(n=27)$ & $p$ value \\
\hline Gender (male) n (\%) & $10(71 \%)$ & $21(78 \%)$ & 0.712 \\
\hline Age (years) & $60 \pm 10$ & $56 \pm 10$ & 0.299 \\
\hline Cirrhosis etiology (alcoholic/non-alcoholic) n (\%) & $13(93 \%) / 1(7 \%)$ & $22(81 \%) / 5(19 \%)$ & 0.645 \\
\hline Child-Pugh score (units) & $6 \pm 1$ & $6 \pm 1$ & 0.674 \\
\hline Child-Pugh class (A/B) n (\%) & $11(79 \%) / 3(21 \%)$ & $20(74 \%) / 7(26 \%)$ & 0.535 \\
\hline MELD score (units) & $8 \pm 3$ & $6 \pm 3$ & 0.088 \\
\hline Ascites n (\%) & $3(21 \%)$ & $1(0.0 \%)$ & 0.107 \\
\hline Gastroesophageal varices $\mathrm{n}(\%)$ & $12(86 \%)$ & $21(78 \%)$ & 0.692 \\
\hline Hemoglobin (g/dL) & $13.3 \pm 1.7$ & $14.3 \pm 1.5$ & 0.064 \\
\hline Sodium (mEq/L) & $138.3 \pm 4.9$ & $139.8 \pm 2.5$ & 0.206 \\
\hline Creatinine $(\mathrm{mg} / \mathrm{dL})$ & $0.9 \pm 0.2$ & $0.8 \pm 0.1$ & 0.200 \\
\hline Albumin (g/dL) & $3.6 \pm 0.6$ & $3.7 \pm 0.5$ & 0.295 \\
\hline INR & $1.3 \pm 0.3$ & $1.2 \pm 0.1$ & 0.217 \\
\hline Ammonia $(\mu \mathrm{mol} / \mathrm{L})$ & $48.5 \pm 13.3$ & $45.6 \pm 15.6$ & 0.555 \\
\hline
\end{tabular}


renal disease, diabetes mellitus and illiteracy), could have influenced our results.

The neuropathophysiology of MHE is not completely understood. ${ }^{29,50,51}$ Hyperammonemia might play a central role. $29,52,53$ In our study, as it was expected, severity of liver function was associated with venous ammonia concentration. However, venous ammonia concentration was not related to the presence of MHE. This finding was also demonstrated by some authors, ${ }^{50,54}$ though data supporting the opposite is also published in the literature.

Hyperammonemia caused by liver dysfunction leads to an increased ammonia load to the brain and, consequently, to the disruption of ammonia cerebral metabolism. Astrocytic swelling and GABAergic and glutamatergic neurotransmission alterations ensue..$^{51,53,54}$ These alterations are probably implicated in the development of MHE. Several structural and functional CNS imaging studies (magnetic resonance imaging and positron emission tomography) have recently shown that subcortical brain areas, such as basal ganglia and cerebellum, may be responsible for primary features of MHE. ${ }^{54-56}$ Nevertheless, imaging studies are not considered as diagnostic methods for $\mathrm{MHE}^{3}$

Two surveys revealed that MHE is not routinely tested in standard clinical practice. ${ }^{57,58}$ Despite universal screening not being mandatory, as there are no clinical guidelines recommending it, the detection of MHE in cirrhotic patients has increasing importance because it can provide useful and meaningful information at the individual level and a plan can tailored accordingly.

The management of patients with MHE includes several approaches. ${ }^{3}$ Assessment of impairment of daily life and working activities, driving and HR-QoL; medical therapy and improvement of the nutritional condition, as cirrhotic patients with muscle depletion have higher risk of developing MHE. ${ }^{59}$ Some subgroups of patients would benefit the most from testing for MHE as quite specific recommendations can be made if it is diagnosed. ${ }^{3}$ Active drivers should be advised that they have diminished driving abilities and an increased probability of road traffic accidents; active workers ought to have their risk at work evaluated and counselling regarding handling complex/dangerous machinery should be provided; patients with cognitive impairment and decline in work performance perceived by themselves, relatives or by colleagues should be assessed and, if possible, changes in daily/working activities should be carried out. As indexes of quality of life specific for MHE are not available, HR-QoL is usually measured by general indexes such as sickness impact profile, medical outcome study short form-36 (SF-
36) or Nottingham health profile questionnaires. Medical therapy for MHE is not consensual. The decision to initiate it ought to be individualized, i.e., based on the estimation of the extent of patient's daily life impairment that can ameliorate with therapy. Recently, some therapeutic options have been proven effective, as they have demonstrated having a positive impact on cognitive function and HR-QoL (lactulose, ${ }^{28-30,32}$ rifaximin, ${ }^{14,27}$ probiotics ${ }^{8,32}$ and L-ornithine L-aspartate $)^{32}$ and preventing the progression to overt HE (lactulose ${ }^{28,30}$ and probiotics), ${ }^{8}$ with minor side effects. Furthermore, optimization of the patient's nutritional condition conducted periodically by a nutritionist has shown benefit in terms of cognitive performance and HR-QoL. ${ }^{60}$

\section{CONCLUSION}

This study, regarding MHE prevalence in Northern Portugal, shows that our reality is in accordance with international reports, confirming that $\mathrm{MHE}$ is a frequent entity and that it is common early in the course of cirrhosis, even in compensated cirrhotic patients. Therefore, physicians should be aware of MHE and actively search for this hidden condition, by choosing a validated tool to make the diagnosis and manage it properly. In our study, strict inclusion criteria were used. Limitations of the current study: it did not consider if PHES is related to clinical endpoints such as the development of overt HE and survival; also, vitamin B12 and folate levels were not assessed and VDRL test was not performed. Future research must address questions regarding the long-term prognosis of $\mathrm{MHE}$ and the benefits of therapeutics options.

\section{PEOPLE AND ANIMALS PROTECTION}

The authors declare that the procedures were followed according to the regulations established by the Clinical Research and Ethics Committee and to the Helsinki Declaration of the World Medical Association. All participants gave written informed consent.

\section{CONFIDENTIALITY OF DATA}

The authors declare having followed the protocols in use at their working center regarding patient's data publication.

\section{CONFLICTS OF INTEREST}

The authors declare that there are no conflicts of interest.

\section{FUNDING SOURCES}

No subsidies or grants contributed to this work.

\section{REFERENCES}

1. Amodio P, Montagnese S, Gatta A, Morgan MY. Characteristics of minimal hepatic encephalopathy. Metab Brain Dis. 2004;19: 253-67.

2. Ferenci $\mathrm{P}$, Lockwood $\mathrm{A}$, Mullen $\mathrm{K}$, Tarter $\mathrm{R}$, Weissenborn $\mathrm{K}$, Blei AT. Hepatic encephalopathy - definition, nomenclature, diagnosis, and quantification: final report of the working party at the $11^{\text {th }}$ World Congresses Gastroenterology, Vienna, 1998. Hepatology. 2002;35:716-21.

3. Ortiz M, Jacas C, Córdoba J. Minimal hepatic encephalopathy: diagnosis, clinical significance and recommendations. J Hepatol.

2005;42:S45-53.

4. Bajaj JS, Wade JB, Sanyal AJ. Spectrum of neurocognitive impairment in cirrhosis: implications for the assessment of hepatic encephalopathy. Hepatology. 2009;50:2014-21

5. Weissenborn K, Ennen JC, Schomerus H, Ruckert N, Hecker H. Neuropsychological characterization of hepatic encephalopathy. J Hepatol. 2001;34:768-73.

6. McCrea M, Cordoba J, Vessey G, Blei AT, Randolph C. Neuropsychological characterization and detection of subclinical 
hepatic encephalopathy. Arch Neurol. 1996;53:758-63.

7. Bahceci F, Yildirim B, Karincaoglu M, Dogan I, Sipahi B. Memory impairment in patients with cirrhosis. J Nat Med Assoc. 2005;97:213-6.

8. Weissenborn K, Heidenreich S, Giewekemeyer K, Ruckert N, Hecker $\mathrm{H}$. Memory function in early hepatic encephalopathy. J Hepatol. 2003;39:320-5.

9. Weissenborn K, Giewekemeyer K, Heidenreich S, Bokemeyer M, Berding G, Ahl B. Attention, memory and cognitive function in hepatic encephalopathy. Metab Brain Dis. 2005;20:359-67.

10. Groeneweg M, Quero JC, De Bruijn I, Hartmann IJ, Essink-bot ML, Hop WC, et al. Subclinical hepatic encephalopathy impairs daily functioning. Hepatology. 1998;28:45-9.

11. Marchesini G, Bianchi G, Amodio P, Salerno F, Merli M, Panella C, et al. Factors associated with poor health-related quality of life of patients with cirrhosis. Gastroenterology. 2001;120:170-8.

12. Wang JY, Zhang NP, Chi BR, Mi YQ, Meng LN, Liu YD, et al. Prevalence of minimal hepatic encephalopathy and quality of life evaluations in hospitalized cirrhotics in China. World J Gastroenterol. 2013;19:498491.

13. Mina A, Moran S, Ortiz-Olvera N, Mera R, Uribe M. Prevalence of minimal hepatic encephalopathy and quality of life in patients with decompensated cirrhosis. Hepatol Res. 2014;44:E92-9.

14. Schomerus $\mathrm{H}$, Hamster W. Quality of life in cirrhotics with minimal hepatic encephalopathy. Metab Brain Dis. 2001;16:37-41.

15. Arguedas MR, DeLawrence TG, McGuire BM. Influence on hepatic encephalopathy on health-related quality of life in patients with cirrhosis. Dig Dis Sci. 2003;48:1622-26.

16. Watanabe A, Tuchida T, Yata Y, Kuwabara Y. Evaluation of neuropsychological function in patients with liver cirrhosis with special reference to their driving ability. Metab Brain Dis. 1995;10:239-48.

17. Wein C, Koch H, Popp B, Oehler G, Schauder P. Minimal hepatic encephalopathy impairs fitness to drive. Hepatology. 2004;39:739-45.

18. Felipo V, Urios A, Valero P, Sanchez M, Serra MA, Pareja I, et al. Serum nitrotyrosine and psychometric tests as indicators of impaired fitness to drive in cirrhotic patients with minimal hepatic encephalopathy. Liver Int. 2013;33:1478-89.

19. Bajaj JS, Saeian K, Schubert CM, Hafeezullah M, Franco J, Varma RR, et al. Minimal hepatic encephalopathy is associated with motor vehicle crashes: the reality beyond the driving test. Hepatology. 2009;50:117583.

20. Ennaifer R, Cheikh M, Hefaiedh R, Romdhane H, Bem Nejma H, Had NB. Minimal hepatic encephalopathy: a better diagnostic to improve prognostic. Presse Med. 2014;43:e127-33

21. Román E, Córdoba J, Torrens M, Torras X, Villanueva C, Vargas V, et al. Minimal hepatic encephalopathy is associated with falls. Am J Gastroenterol. 2011;106:476-82.

22. Romero-Gomez M, Boza F, Garcia-Valdecasas MS, Garcia E, AguilarReina J. Subclinical hepatic encephalopathy predicts the development of overt hepatic encephalopathy. Am J Gastroenterol. 2001;96:271823.

23. Saxena N, Bhatia M, Joshi YK, Garg PK, Dwivedi SN, Tandon RK. Electrophysiological and neuropsychological tests for the diagnosis of subclinical hepatic encephalopathy and prediction of overt encephalopathy. Liver. 2002;22:190-7.

24. Romero-Gómez M, Córdoba J, Jover R, Olmo Juan, Ramirez M, Rey Rámon, et al. Value of the critical flicker frequency in patients with minimal hepatic encephalopathy. Hepatology. 2007;45:879-45.

25. Hartmann IJ, Groeneweg M, Quero JC, Beijeman SJ, de Man RA, Hop WC, et al. The prognostic significance of subclinical hepatic encephalopathy. Am J Gastroenterol. 2000;95:2029-34.

26. Amodio P, Del Piccolo F, Marchetti P, Angeli P, Lemmolo R, Caregaro L, et al. Clinical features and survival of cirrhotic patients with subclinical cognitive alterations detected by the number connection test and computerized psychometric tests. Hepatology. 1999;29:1662-7.

27. Sidhu SS, Goyal O, Mishra BP, Sood A, Chhina RS, Soni RK. Rifaximin improves psychometric performance and health-related quality of life in patients with minimal hepatic encephalopathy (the RIME Trial). Am J Gastroenterol. 2011;106:307-16.

28. Luo M, Li L, Lu CZ, Cao WK. Clinical efficacy and safety of lactulose for minimal hepatic encephalopathy: a meta-analysis. Eur J Gastroenterol Hepatol. 2011;23:1250-7.

29. Prasad S, Dhiman RK, Duseja A, Chawla YK, Sharma A, Agarwal R. Lactulose improves cognitive functions and health-related quality of life in patients with cirrhosis who have minimal hepatic encephalopathy. Hepatology. 2007;45:549-59.

30. Ziada DH, Soliman HH, EL Yamany SA, Hamisa MF, Hasan AM. Can lactobacillus acidophilus improve minimal hepatic encephalopathy? A neurometabolite study using magnetic resonance spectroscopy. Arab J Gastroenterol. 2013;14:116-22.

31. Patidar KR, Bajaj JS. Antibiotics for the treatment of hepatic encephalopathy. Metab Brain Dis. 2013;28:307-12.

32. Mittal VV, Sharma BC, Sharma P, Sarin SK. A randomized controlled trial comparing lactulose, probiotics and L-ornithine L-aspartate in treatment of minimal hepatic encephalopathy. Eur J Gastroenterol Hepatol. 2011;23:725-32.

33. Randolph C, Hilsabeck R, Kato A, Kharbanda P, Li YY, Mapelli D, et al. Neuropsychological assessment of hepatic encephalopathy: ISHEN practice guidelines. Liver Int. 2009;29:629-35.

34. Weissenborn K. Psychometric tests for diagnosing minimal hepatic encephalopathy. Metab Brain Dis. 2013;28:227-9.

35. Bajaj JS, Saeian K, Verber MD, Hischke D, Hoffmann RG, Franco J, et al. Inhibitory control test is a simple method to diagnose minimal hepatic encephalopathy and predict development of overt hepatic encephalopathy. Am J Gastroenterol. 2007;102:754-60.

36. Lauridsen MM, Jepsen P, Vilstrup $H$. Critical flicker frequency and continuous reaction times for the diagnosis of minimal hepatic encephalopathy: a comparative study of 154 patients with liver diseaswe. Metab Brain Dis. 2011;26:135-9.

37. Amodio P, Gatta A. Neurophysiological investigation of hepatic encephalopathy. Metab Brain Dis. 2005;20:369-79.

38. Amodio P, Valenti P, Del Piccolo F, Pellegrini A, Schiff S, Angeli P, et al. P300 latency for the diagnosis of minimal hepatic encephalopathy: evidence that spectral EEG analysis and psychometric tests are enough. Dig Liver Dis. 2005;37:861-8.

39. Sandford NL, Saul RE. Assessment of hepatic encephalopathy with visual evoked potentials compared with conventional methods. Hepatology. 1988;8:1094-8.

40. Moon JH, Jun DW, Yum MK, Lee KN, Lee HL, Lee OY, et al. Prolonged N200 is the early neurophysiological change in the patient with minimal hepatic encephalopathy. Scand J Gastroenterol. 2014;49:604-10.

41. Maldonado-Garza HJ, Vázquez-Elizondo G, Gaytán-Torres JO, FloresRendón AR, Cárdenas-Sandoval MG, Bosques-Padilla FJ. Prevalence of minimal hepatic encephalopathy in cirrhotic patients. Ann Hepatol. 2011;10:S40-4.

42. Torlot FJ, McPhail MJ, Taylor-Robinson SD. Meta-analysis: the diagnostic accuracy of critical flicker frequency in minimal hepatic encephalopathy. Aliment Pharmacol Ther. 2013;37;527-36.

43. Pinho M, Cerqueira R, Peixoto B. Psychometric hepatic encephalopathy score normalization data for the Portuguese population. Acta Med Port. 2011;24:S319-26.

44. Amodio P, Campagna F, Olianas S, lannizzi P, Mapelli D, Penzo M, et al. Detection of minimal hepatic encephalopathy: normalization and optimization of the psychometric hepatic encephalopathy score. A neuropsychological and quantified EEG study. J Hepatol. 2008;49:34653.

45. Groeneweg M, Moerland W, Quero JC, Hop WC, Krabbe P, Schalm SW. Screening of subclinical hepatic encephalopathy. J Hepatol. 2000;32:748-53

46. Gad YZ, Zaher AA, Moussa NH, El-desoky AE, Al-Adarosy HA Screening for minimal hepatic encephalopathy in asymptomatic drivers with liver cirrhosis. Arab J Gastroenterol. 2011;12:58-61.

47. Li SW, Wang K, Yu YQ, Wang HB, Li YH, Xu JM. Psychometric hepatic encephalopathy score for diagnosis of minimal hepatic encephalopathy in China. World J Gastroenterol. 2013;19:8745-51.

48. Das A, Dhiman RK, Saraswat VA, Verma M, Naik SR. Prevalence and natural history of subclinical hepatic encephalopathy in cirrhosis. $J$ Gastroenterol Hepatol. 2001;16:531-5.

49. Senzolo M, Amodio P, D'Aloiso MC, Fagiuoli S, Del Piccolo F, Canova $D$, et al. Neuropsychological and neurophysiological evaluation in cirrhotic patients with minimal hepatic encephalopathy undergoing liver transplantation. Transplant Proc. 2005;37: 1104-7.

50. Shawcross DL, Wright G, Olde Damink SW, Jalan R. Role of ammonia and inflammation in minimal hepatic encephalopathy. Metab Brain Dis. 2007;22:125-38

51. Kappus MR, Bajaj JS. Covert hepatic encephalopathy: not as minimal as you might think. Clin Gastronterol Hepatol. 2012;10:1208-19.

52. Romero-Gómez M, Grande L, Camacho I, Benitez S, Irles JÁ, Castro M. Altered response to oral glutamine challenge as prognostic factor for overt episodes in patients with minimal hepatic encephalopathy. $J$ Hepatol. 2002;37:781-7.

53. Bismuth M, Funakoshi N, Cadranel JF, Blanc P. Hepatic encephalopathy: from pathophysiology to therapeutic management. Eur J Gastroenterol 
Hepatol. 2011;23:8-22.

54. Ahl B, Weissenborn K, Van den Hoff J, Fischer-Wasels D, Kostler $\mathrm{H}$, Hecker $\mathrm{H}$, et al. Regional differences in cerebral blood flow and cerebral ammonia metabolism in patients with cirrhosis. Hepatology. 2004;40:73-9.

55. Rikkers L, Jenko P, Rudman D, Freides D. Subclinical encephalopathy: detection, prevalence, and relationship to nitrogen metabolism. Gastroenterology. 1978;75: 462-9.

56. Weissenborn K, Bokemeyer M, Ahl B, Fischer-Wasels D, Giewekemeyer $\mathrm{K}$, Van den Hoff $\mathrm{J}$, et al. Functional imaging of the brain in patients with liver cirrhosis. Metab Brain Dis. 2004;19:269-80.

57. Bajaj JS, Etemadian A, Hafeezullah M, Saeian K. Testing for minimal hepatic encephalopathy in the United States: an AASLD survey. Hepatology. 2007;45: 833-4.
58. Vergara Gómez $\mathrm{M}$, Flavià-Olivella $\mathrm{M}$, Gil-Prades $\mathrm{M}$, Dalmau Obrador B, Córdoba-Cardona J. Diagnosis and treatment of hepatic encephalopathy in Spain: results of a survey of hepatologists. Gastroenterol Hepatol. 2006;29:1-6.

59. Merli M, Giusto M, Lucidi C, Giannelli V, Pentassuglio I, Di Gregorio V, et al. Muscle depletion increases the risk of overt and minimal hepatic encephalopathy: results of a prospective study. Metab Brain Dis. 2013;28:281-4

60. Kato A, Tanaka H, Kawaguchi T, Kanazawa H, Iwasa M, Sakaida I, et al. Nutritional management contributes to improvement in minimal hepatic encephalopathy and quality of life in patients with liver cirrhosis: a preliminary, prospective, open-label study. Hepatol Res. 2013;43:452-8 


\section{Minimal Hepatic Encephalopathy: The Reality Beyond Our Eyes}

Acta Med Port 2015:28:480-485

Publicado pela Acta Médica Portuguesa, a Revista Científica da Ordem dos Médicos

Av. Almirante Gago Coutinho, 151

1749-084 Lisboa, Portugal.

Tel: +351218428215

E-mail: submissao@actamedicaportuguesa.com

www.actamedicaportuguesa.com

ISSN:0870-399X | e-ISSN: 1646-0758

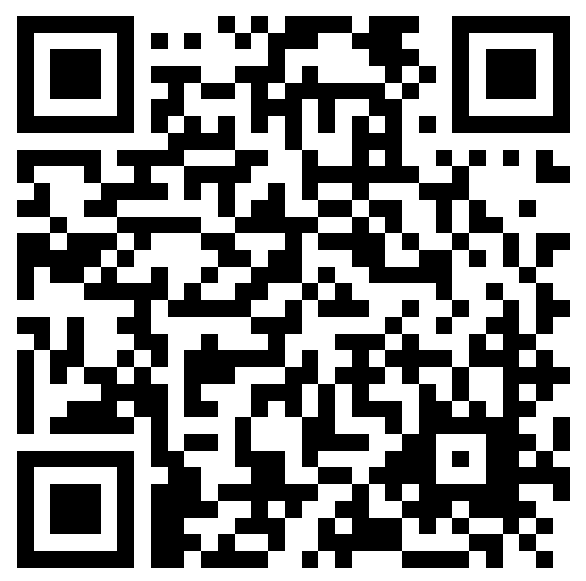

